\title{
Food Security and The Role of Higher Education
}

\author{
Dede Rosyada \\ Syarif Hidayatullah Islamic State University \\ J1. Ir. H. Juanda No. 95, Ciputat 15412 Jakarta \\ dede.rosyada@uinjkt.ac.id
}

\begin{abstract}
Food security has become a necessary issue in Indonesia. Enhancing food security is being the most priority for Indonesian government, because food is a basic need for every people in the world. The problems are balance of food, diversification and distribution. Food security is being a national, regional and even world issues. Indonesia, actually as a tropical country, is the one of some appropriate countries for agriculture. But, the facts are still indicating that Indonesia is one of the insecure countries in the world, because of two aspects, the slowly of increasing productivity, and uneven distribution problems that relates to the public purchasing capacity. In this study, we provide a review and views on food security, some policies for food security, and the role of higher education to promote food security.
\end{abstract}

Keywords: Food security, Policies, Food, Higher education

\section{Introduction}

Food security has become a central issue in the framework of agricultural development and national development, shown in part by the issue of food security as one of the focuses of operational policies on agricultural development in the Cabinet Unity of National (1999-2004) in addition to the other focus is the development of agribusiness. In addition, the establishment of a special institution that handles the food insecurity issue, the echelon I Food Security Level I Agency in the scope of the Department of Agriculture in 2000 and then in 2001 was changed to the Board of Guidance for Food Security, that indicates the importance of food security. The establishment of such institute is expected to consolidate a system of domestic resilience for local interests, due to the change of the international and domestic strategic environment. The uncertainty and instability of national food production, cannot automatically rely on food availability at the world market [1].

Enhancing food security is being the most priority for Indonesian government, because food is a basic need for every people in the world. The problems are balance of food, diversification and distribution. Balance of foods means balance between level of productivity and the needs of consumption, and then equitable distribution. The rice productivity until 2012 is attaining 38 million tons per year, while the need for consumption is about 34 million tons. So, productivity of farming is surplus 4 million tons per year, but the targeted surplus is 10 millions tons per year, so, Indonesian government is still importing rice about 6 million tons per year just to backup food stock [2]. Why Indonesia has to have enough food stock, it is because Indonesia is still not secure from flood, disaster, and earth quake. And then, Indonesia is still threatened by starving and malnutrition. It is something odd, because the country has a surplus rice stock, but in the other part of the country precisely starving and malnutrition. These are the two main problems concerning food security, thus, what to do to solve the problems, and to prepare the next future for achieving prosperity, justice and social welfare for all the citizens equally.

\section{Some Policies for Food Security}

Food security is being a national, regional and even world issues. Indonesia, actually as a tropical country, is the one of some appropriate countries for agriculture. But, the facts are still indicating that Indonesia is one of the insecure countries in the world, because of two aspects, the slowly of increasing productivity, and uneven distribution problems that relates to the public purchasing capacity. Food security as it was defined by FAO is availability at all times of adequate world food supplies of basic foodstuffs to sustain a steady expansion of food consumption and to offset fluctuations in production and price [3]. The stressing point of food security is the availability and distribution until the last chain. It means that foods stock can de distributed until the people in the family, and they can access it by purchasing with the affordable price.

According to the bill of food, food resilient requires some qualification as follows [4]:

1. The fulfillment of needs of the food for the state until individual level

2. The measure of the fulfillment of needs of the food includes various aspects, namely

a. In term of quantity; the State can fulfill all the needs of the food

b. In term of quality; the State can fulfill good quality foods, safe for consumption, providing a lot of varieties, and have nutritional adequacy

c. In term of religion spirituality; the foods are not forbidden by religious regulation, and compatible with belief and culture

d. In terms of economic affordability, the foods are equally available for all 
e. Indonesian citizens, and can be purchased by all components of society in affordable prices

3. The availability and affordability of these foods are intended for the community to live healthy, active, productive and sustainable [4].

There are three important components to enhance and maintain food resilient, availability, affordability, and quality. In term of availability, actually Indonesia doesn't have a serious problem, because as it is mentioned above that rice production of Indonesia is slightly above of the consumption, and rice import is done to strengthen food reserves, whereas Indonesia is still threatened by drought disaster, hunger, flood, earth quake, and also uneven distribution. Availability is also influenced by equitable distribution. In this context, the State is giving a wide opportunity for private enterprise to participate in distribution, so it efficiently reach the lowest level of the community. There is a very strategic political decision from the ministry of agriculture, that the ministry has a great effort to push rice production, diversification of foods, and managing food stock by logistic board. So, the government easily come in, whenever the problem is coming.

In term of the food affordability, the important element of food policy is a guaranty for poor communities to have access to the healthy and nutritious food. The best ways to achieve the mission to comply food demand of the poor communities are expanding economic growth that gives beneficial impacts for the poor people. Such program can be developed by direct aids for poor societies to ease their life and to push them for more independent. The recent policies of the government to distribute direct aids among others are; rice for poor that has been distributed since early of twenty first century, for more than 9 million families, effort of logistic board to hold the rice price, and minimizing obstacles of domestic trade mobility, that can push domestic price higher than the world price. The most important policy to maintain food affordability for poor is controlling food price, and food distribution. If the government, through logistic board, can hold the price of rice, and control the distribution, all people can get access to it well.

In term of the quality, it can be maintained by controlling the sufficient, healthy and nutritious foods for poor. For those mission, the government develops some strategic programs as follows:

1. Protecting some important commodities of foods

2. Introducing some additional foods

3. Disseminating information about nutrition

Actually, the poor communities don't have enough food stock, because they don't have enough money to purchase rice and other additional foods. But the government subsidies them by holding the price below market price, so they can get enough, healthy and nutritious food from the government. In addition, the government also introducing additional food, it is like corn, cassava and so forth.

The latest policies for food security and have been decided by the bill number 7 year 1996, and then was elaborated in the Government Regulation number 98 year 2002, the strategies and policies of food resiliences are as follows [5]:

1. Food availability that is implemented by developing production system, efficiency in food business, food production technology, facilities and infrastructure food production, and maintaining productive areas.

2. National food reserves both community and government. Government food reserves are provided by the government from district level, provincial government until central government. While community food reserves are provided by non government organization, social organization, privates enterprises, cooperation and also personal efforts.

3. Food diversification, it means diversification of food consumption under the principle of nutritious balance.

4. Preventing and handling food problems by implementing anticipation step to avoid food problem (more or less of food and the ability of each family to fulfill the need of food).

5. The role of government and society is implementing food resilience policies in his/her areas, through dissemination of informations, Then, enhancing social motivation and the independent of the family.

6. Improving the capacity of human resources and developing international collaboration. The developing of human resource is implemented through education and training about food, disseminating science and technology in the field of food, and the 8 n food concealing and international relationship in the field of production, trading, and food distortion, food reserves, preventing and handling food problems, and then research and technology for food.

Those are some political decisions about food resilience in Indonesia, in anticipating the unbalance future between population growth that is still positive $1.25 \%$ per year, while the land for planting rice as a main food for Indonesia is static, and even some parts of rice field are converted to be housing, industrial park, official government and so forth. Indonesia is facing big problem for the future, as it doesn't change the political decision for food resilience. Therefore, the action programs that has been decided by the government since year 2009, are mostly to conserve the land, expanding new land for planting rice, and maintain the existing land. Expanding new land, actually isn't easy, it needs a lot of capital to be invested, and also it needs other infrastructure [6]. So far, the planing for food security, Indonesia is still in the base line programs, and mechanization of farming, cultivating, planting and harvesting. Indonesia is still pretending agriculture just for maintaining availability of food, distributing and selling in an affordable price. Thus, all citizens can feed well, healthy and nutritious.

The other program is empowering food resilience for regional government inline with the political decision that gives the authority of agriculture to the district and province. Such decision was influenced by 
the fact that Indonesia has a lot of varieties of region potentiality, so, the farming industry can be diversified not only just ice but also non-rice farming. And also, not only planting and harvesting rice, but also producing it for being the other varieties of food, and the farmers will get a lot of additional values as new income generating by creative economy. The main goal of food resilience in household level is enhancing a purchase power through enhancement of incomes and revenue [5]. Responsibility of food resilience at the level of family is under the hand of head of the family. Hence, husband that commonly as a head of household in Indonesia tradition, is responsible to empower, initiate and push all the family members to participate in all production process, as part of promoting the development of nation. However, the community cannot work alone, they need to be inspired by new discovery, new technology, and also new knowledge for promoting business work, extending business networking, and also enhancing competence in business management. For those purposes, scientist from universities should come down to the society, to assist them and train them for new knowledge, new skill and new technology.

\section{The Role of Higher Education}

Higher education in Indonesia has three basic functions, organizing teaching and learning to educate all students for being smart citizens, innovative and creative human resource and can promote the nation to be developed country, respected by the world and has a great nation dignity. But, for this purpose, all professors and lecturers have to organize research to get some new discoveries, new technologies, and also new instruments to be used by the communities, whether for industrial sectors, home industries, or for small and micro business working. Actually, intellectual products are knowledge, science, technology and instrument, but before disseminating for being used by the community for professional working, those new discoveries should be validated by them through the university program, namely community outreach. It means, that the academicians from higher education, come down to the community to validate their theories, technologies or instruments, to be disseminated for the community to be used for promoting the nation to be developed country in the world.

The position of higher education is very strategic to bring the country for growing up. The prominent function of higher education, is stipulated in the bill number 12 year 2012, in the article number five point number $\mathrm{c}$ and $\mathrm{d}$, that the goal of organizing higher education are:

1. Producing new science and technology through scientific research by paying attention to the humanities values, to get a lot of beneficial for the developing of the nation and civilization in achieving the goal of the country prosperous, justice and social welfare.

2. Implementing community outreach based on reasoning thinking, new discovery of scientific research and get a lot of benefits for developing pubic prosperity and assisting the community to promote the smartness of the citizens [7].

Inline with the bill of higher education, the strategic planning of national research activities as it is mentioned in Ministerial decree number 13 year 2015 about strategic planning Ministry of Research and higher Education Year 2015-2019, that research activities are directed to develop new technology and its implementation will support for:

1. The competitiveness of goods and services

2. Sustainability and utility of natural resource

3. Preparing Indonesian citizens to be the global society and welcoming the globalization era [8]

Therefore, the university research as main activities of professors and lecturers aren't precisely free from sociological and political context, because such activities are being parts of the national agendas to enhance the quality of the country, to develop the nation dignity and to be respected by the world. To be respected, each nation should have a positive economical growth, discovered a lot new theories, new technologies and new instrument to be used and implemented by the society, whether in industry, trading, business networking, or even in the official work. The recent phenomena of the world, that the development of the country is more determined by creativity, innovation and in the field of services instead of exploring natural resource. Therefore, all professors and lecturers from the faculty of science and technology are expected to develop creative research, innovative research to discover new technology or new instruments to be implemented in the professional works, to achieve the goals of the nation prosperity, justice and social welfare, and to promote the human civilization.

\section{Conclusion}

Indonesia now in the serious working to maintain food security, because birth rate is still positive $1.25 \%$ per year, while at the same time the size of farming lands is always restricted by new building for industrial parks, housing and even for official government. The government gives up, and cont do anything except maintaining the existing land, and optimizing the utility of the land for planting food particularly rice as a main food. There three political decisions to strengthen food security for the people of Indonesia, availability, affordability, and quality. In term of availability, nowadays, Indonesia still not in a serious problematic situation, because the productivity of rice farming is still enough for consumption, but Indonesia is still importing for food stock and reserves, because Indonesia is still threatened by drought disaster, flood, and also the unreachable distribution to the lowest level of the society. Otherwise they can get the distribution of food but the prices are above their capacity to purchase. So, the government should come for guaranty of affordability to avoid hunger disaster. The last one of food security policies i.e. quality, it means that the Indonesian citizens can get enough food, healthy and nutritious. So the people of Indonesia will 
consume enough, healthy and nutritious food, so they will find prosperity and justice,

For supporting the programs, all institutions of higher educations, should develop their research to get a lot of new theories, new technologies and new instruments inline with the programs of food security. Hence, the focus of their research should be on creative and innovative farming, farming in a narrow land, planting rice on dry land, and so forth. And also the research should be directed to find new idea how reproduce rice to the kinds of meals, that can get new additional values, that can assist the rural citizens to be productive people and are inspired by the propel for higher education. That is the real community outreach.

\section{References}

[1] Handewi, P. S., Rahman \& Mewa, A. Ketahanan Pangan; Konsep, Pengukuran dan Strategi. Forum Penelitian Agro Ekonomi 20(1), 12-24.

[2] Siringo, H. B., \& Daulay, M. (2014). Analisis Keterkaitan Produktivitas Pertanian Dan Impor Beras Di Indonesia. Ekonomi dan Keuangan, 2(8).

[3] Upton, J. B., Cissé, J. D., \& Barrett, C. B. (2016). Food security as resilience: reconciling definition and measurement. Agricultural Economics, 47(S1), 135147.

[4] Suryana, A. (2014). Menuju Ketahanan Pangan Indonesia Berkelanjutan 2025: Tantangan dan Penanganannya. Forum penelitian Agro Ekonomi 32(2), 123-135.

[5] Purwaningsih, Y. (2008). Ketahanan Pangan: Situasi, Permasalahan, Kebijakan, dan Pemberdayaan Masyarakat. Jurnal Ekonomi Pembangunan: Kajian Masalah Ekonomi dan Pembangunan, 9(1), 1-27.

[6] Tambunan, T. (2008). Ketahanan pangan di Indonesia: inti permasalahan dan alternatif solusinya. Makalah dalam Kongres ISEI. Mataram.

[7] Bill of Higher Education Number 12 Year 2012, Article number 5, point $\mathrm{c}$ and $\mathrm{d}$.

[8] Attachment of Ministerial Regulation, Ministry of Research and Higher Education, Number 13 year 2015, Chapter III, p. 23. 